\title{
INFLUENCE OF AUSTEMPERING TIME AND AUSTEMPERING TEMPERATURE IN MICROSTRUCTURE AND MECHANICAL PROPERTIES IN AUSTEMPERED DUCTILE IRON
}

\author{
Giulliana Victória Tissi ${ }^{*}{ }^{\natural}$, Gláucio Soares da Fonseca ${ }^{2}$ \\ ${ }^{*}$ Graduate Program on Mechanical Engineering, Federal Fluminense University, Brazil \\ ${ }^{2}$ Graduate Program on Metallurgical Engineering, Federal Fluminense University, Brazil
}

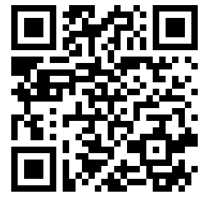

DOI: https://doi.org/10.29121/granthaalayah.v8.i6.2020.419

Article Type: Research Article

Article Citation: Giulliana Victória

Tissi, and Gláucio Soares da

Fonseca. (2020). INFLUENCE OF

AUSTEMPERING TIME AND

AUSTEMPERING TEMPERATURE IN

MICROSTRUCTURE AND

MECHANICAL PROPERTIES IN

AUSTEMPERED DUCTILE IRON.

International Journal of Research -

GRANTHAALAYAH, 8(6), 51-62.

https://doi.org/10.29121/granthaa

layah.v8.i6.2020.419

Received Date: 02 May 2020

Accepted Date: 20 June 2020

Keywords:

Austempered Ductile Iron (Adi)

Austempering Temperature

Austempering Time

Microstructure

Hardness

Impact

\section{ABSTRACT}

Austempered Ductile Iron (ADI) has excellent mechanical properties related to its microstructure ausferrite, and with the cycle of austempering heat treatment, many mechanical properties can be obtained from the same alloy, simply changing the time and temperature. To evaluate the influence of austempering time and temperature on the ADI, analyzed the modifications in the microstructures and mechanical properties of the samples of ductile iron, subjected to austempering heat treatment with austenitizing time and temperature of $910{ }^{\circ} \mathrm{C}$ and 90 minutes and during the austempering bath, the samples were submitted to different temperatures, $300,320,340,360$ e $380{ }^{\circ} \mathrm{C}$, and for four different times for each temperature, 75, 110, 145 and 180 minutes. For the microstructural analysis, the microscopic techniques were used: optical and scanning electron and mechanical properties were obtained by mechanical testing of hardness and impact. The results show that there is a relationship between austempering temperature with microstructure and mechanical properties. The highest retained austenite and energy absorbed were $25.73 \%$ and $130 \mathrm{~J}$, respectively, for the austempered sample at $380{ }^{\circ} \mathrm{C}$ and 180 minutes and the highest hardness value was $458 \mathrm{HB}$ for the austempered sample at $300^{\circ} \mathrm{C}$ and 75 minutes.

\section{INTRODUCTION}

A special family of nodular cast irons is austempered. Austempered Ductile Iron (ADI) is nodular cast iron, that was submitted to austempering treatment, whose mechanical properties can be improved through this treatment. ADI exhibits excellent combinations of high strength, toughness, fatigue strength, and wear resistance. Because of these unique properties, ADI is used extensively in many engineering applications, including in the automotive industry as gears, crankshafts, and connecting rod. When ductile iron is subjected to an austempering treatment, the range of mechanical properties is obtained depending on heat treatment parameters such as austenitizing time and temperature and austempering time and temperature, and thus, the number of applications for this type of cast iron is increased. The excellent mechanical properties of ADI are related to its microstructure. When ductile iron is

(C) 2020 The Author(s). This is an open access article distributed under the terms of the Creative Commons Attribution License, which permits unrestricted use, distribution, and reproduction in any medium, provided the original author and source are credited. 
Influence of Austempering Time and Austempering Temperature in Microstructure and Mechanical Properties in Austempered Ductile Iron

austempered, it produces a microstructure that consists of ferrite $(\alpha)$ and high carbon austenite $\left(\gamma_{H C}\right)$ with graphite nodules dispersed in it [1], [2], [3], [4], [5], [6], [7].

Austempering treatment to obtain the ADI firstly consists of heating of the nodular cast iron to the austenitization temperature in the temperature range of $850-950^{\circ} \mathrm{C}$. After holding at the temperature to create a fully austenitic matrix for $1.0-3.0 \mathrm{~h}$, the material is cooled rapidly to a temperature of an isothermal transformation of austenite, in the range of $230-400^{\circ} \mathrm{C}$. Quenching from austenitizing temperature to austempering temperature should be rapid enough to avoid the formation of pearlite to maximize toughness. The iron is then held at this temperature for the required length of time for the austempering reaction to occur, for 0.5 - $4 \mathrm{~h}$, followed by cooling to room temperature [2], [3], [4], [8], [9].

The austempering reaction in ADI occurs in two stages. In the first reaction, the austenite $(\gamma)$ decomposes into ferrite $(\alpha)$ and high carbon austenite $\left(\gamma_{H C}\right)$, termed as ausferrite $[1,2,3,10,11]$. This reaction can be represented by Eq. 1:

$$
\gamma \rightarrow \alpha+\gamma_{H C}
$$

If the casting is held at the austenitizing temperature for too long, then a second undesirable reaction takes place because it produces embrittlement in ADI. In this case, the high carbon austenite $\left(\gamma_{H}\right)$ can decompose into ferrite and carbide $(\varepsilon)[2,9,12,13,14]$. This reaction can be represented by Eq. 2 :

$$
\gamma_{H C} \rightarrow \alpha+\varepsilon
$$

Thus, the best combination of mechanical properties is obtained in ADI, after the completion of the first stage but before the onset of the second stage. The period between the completion of the first stage and the onset of the second stage is termed as the process window [10], [13].

The austempering time and temperature directly influence the mechanical properties of ductile iron alloy. Lower austempering temperatures, it has high hardness, due to the presence of a very thin ferrite. Higher austempering temperature produces a coarser ferrite with an increased volume fraction of retained austenite, resulting in a significant increase in toughness with higher values of energy absorbed in impact test [1], [4], [9], [12].

The high potential of the ADI in both cost and versatility, that it presents around its properties, and the influence that austempering time and the temperature has on the mechanical properties of nodular cast iron, generates the motivation for choosing the theme of this article. To evaluate the influence of austempering time and temperature on the ADI, the modifications in the microstructures, hardness, and energy absorbed in impact test were analyzed in samples of nodular cast iron with equal chemical composition, subjected to austempering heat treatment with equal austenitizing time and temperature and different austempering time and temperature. The results of this study show that at the lower austempering temperature, the hardness is high and at the higher austempering temperature, both, the volume fraction of austenite retained, and the energy absorbed by impact test are higher.

\section{MATERIALS AND METHODS}

\subsection{MATERIALS}

The chemical composition of ductile cast iron used in this study is presented in Table 1. At first, the samples had average dimensions of $60 \times 15 \times 15 \mathrm{~mm}$.

Table 1: Chemical composition of ductile cast iron

\begin{tabular}{|c|c|c|c|c|c|c|c|c|c|c|c|}
\hline \multicolumn{10}{|c|}{ Chemical composition (\%) } \\
\hline $\mathrm{C}$ & $\mathrm{Si}$ & $\mathrm{Mn}$ & $\mathrm{P}$ & $\mathrm{S}$ & $\mathrm{Cr}$ & $\mathrm{Ti}$ & $\mathrm{Sn}$ & $\mathrm{Cu}$ & $\mathrm{Mg}$ & $\mathrm{Mo}$ & $\mathrm{Ni}$ \\
\hline 3.41 & 3.11 & 0.16 & 0.05 & 0.009 & 0.060 & 0.014 & 0.006 & 0.666 & 0.042 & 0.293 & 0.616 \\
\hline
\end{tabular}




\subsection{HEAT TREATMENT}

The samples were subjected to twenty distinct austempering heat treatments. All samples were submitted to austenitization time and temperature of 90 minutes and $910^{\circ} \mathrm{C}$ and during the austempering bath, the samples were submitted to different temperatures, $300,320,340,360$ e $380^{\circ} \mathrm{C}$, and for four different times for each temperature, $75,110,145$ and 180 minutes. The austenitizing temperature and time were selected to create a fully austenitic matrix. Austempering was done at 5 different temperatures and 4 different times to study the effect of the austempering temperature and time on mechanical properties and microstructural evolution.

\subsection{MICROSTRUCTURAL ANALYSIS}

Metallographic samples were taken from each of the heat-treated condition, including the as-cast alloy. For microstructure investigations, conventional optical microscopy (OM) and scanning electron microscopy (SEM) were employed. These samples were prepared following standard procedures for optical and scanning electronics analysis. Samples were subjected to grinding, polishing, using different grades of emery papers, and finally, fine polishing. Then the samples were etched using Beraha's reagent, composed of $20 \mathrm{ml}$ of HCL, $80 \mathrm{ml}$ of distilled water, and $1 \mathrm{~g}$ of potassium metabisulfite, for a few seconds and microstructural evolutions were investigated using optical microscopy.

The microstructure was observed in the Olympus BX51M microscope using different magnifications and mode of observations. To classify the graphite nodules, the ASTM A247-17 standard was used to obtain the form (from I, nodular shape, to VII, flake shape) and the size of the nodule (1 to 8). To obtain the nodule count and nodularity, the ASTM E2567-16a standard was followed and the ImageJ program was used. The percentage of nodules present and the volumetric fraction of austenite retained were also obtained using ImageJ.

To obtain micrographs with high magnification capacity and high resolution, of the sample surface, scanning electron microscopy was used. The Zeiss scanning electron microscope, model EVO MA10, which operates with lanthanum hexaboride (LaB6) filaments, was used to obtain micrographs using the secondary electron mode. Five micrographs were recorded per sample in different regions, with 2000x magnification. Through the SEM, after the samples had been submitted to the impact test, fracture behavior was analyzed.

\subsection{MECHANICAL TESTING}

The hardness testing of as-cast and austempered samples was carried out using a Brinell Hardness Test at a $3000 \mathrm{kgf}$ applied load, using a $10 \mathrm{~mm}$ diameter steel ball. To determine the hardness, it was necessary to prepare the surface of the samples. For each specimen condition, 10 readings were taken and averaged to represent the hardness values. The Brinell hardness tests were performed based on ASTM standard ASTM E10-18.

Charpy tests were carried out following the ASTM E23-16b standard and were performed at room temperature in unnotched specimens with impact pendulum, $300 \mathrm{~J}$ capacity, Heckert brand. One specimen was used for each heattreated condition in Charpy impact tests and dimensions for the specimens were $55 \times 10 \times 10 \mathrm{~mm}$.

\section{RESULTS AND DISCUSSIONS}

Figure 1 shows the microstructures of the samples observed by an optical microscope. In the as-cast sample (Fig. 1a), the micrograph shows a structure containing dispersed graphite nodules (black) in a matrix pearlitic. A ferrite layer is observed around the graphite nodules, commonly called bull's eye. The microstructures, captured at five different austempering temperatures $300,320,340,360$ and $380{ }^{\circ} \mathrm{C}$ are shown in Fig. $1 \mathrm{~b}-\mathrm{f}$, respectively. For illustration effect, only the micrographs of the samples treated in 75 minutes are shown, because we verified that the temperature had a greater influence than the time. The microstructure of the austempered samples (Fig. 1b-f) contains dispersed graphite nodules in a matrix composed of acicular ferrite and austenite, also known as ausferrite. The dark needle-like structures are called acicular ferrite and white regions are called carbon-enriched austenite.

Figure 2 shows the SEM micrographs, of the as-cast sample (Fig. 2a) and samples treated (Fig. 2b-f) with the same austempering time, 75 minutes, and different austempering temperatures $300,320,340,360$ and $380{ }^{\circ} \mathrm{C}$. In Figure 2a, the perlite lamellae are better defined compared to Figure 1a. Analyzing the sequence of Fig. $2 \mathrm{~b}$ to $2 \mathrm{f}$, it is 
observed that the microstructure becomes coarse with an increase in austempering temperature and consequently the hardness tends to decrease. As the austempering temperature increases the carbon content of austenite also increases. During austempering, ferrite needles nucleate out of austenite. As the austempering happens, these ferrite needles grow and the remaining austenite continues to absorb carbon and the carbon amount of the austenite thus increases.

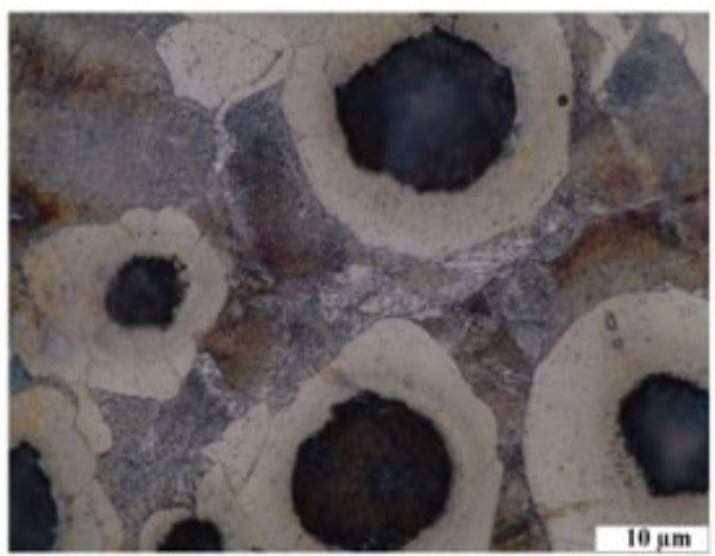

(a)

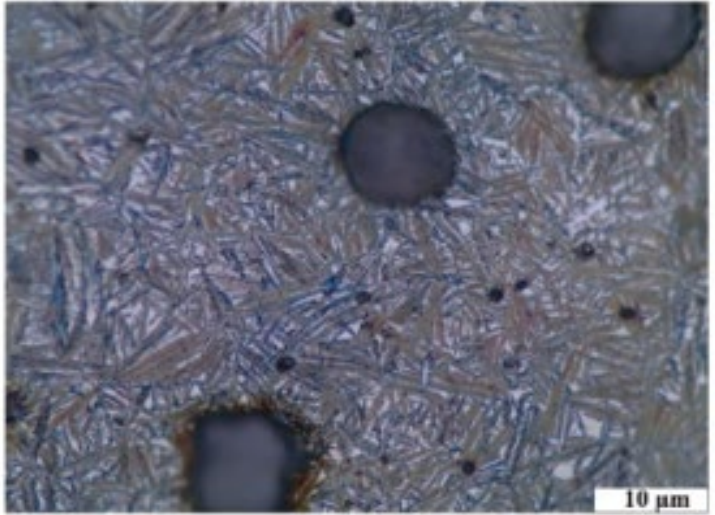

(c)

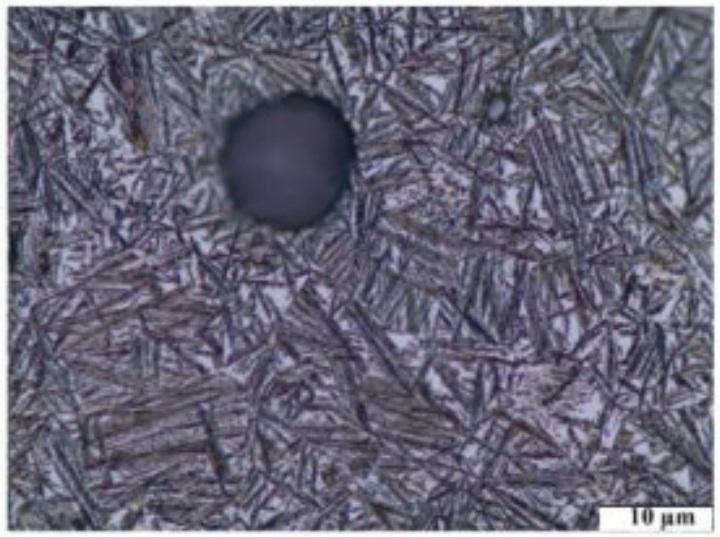

(e)

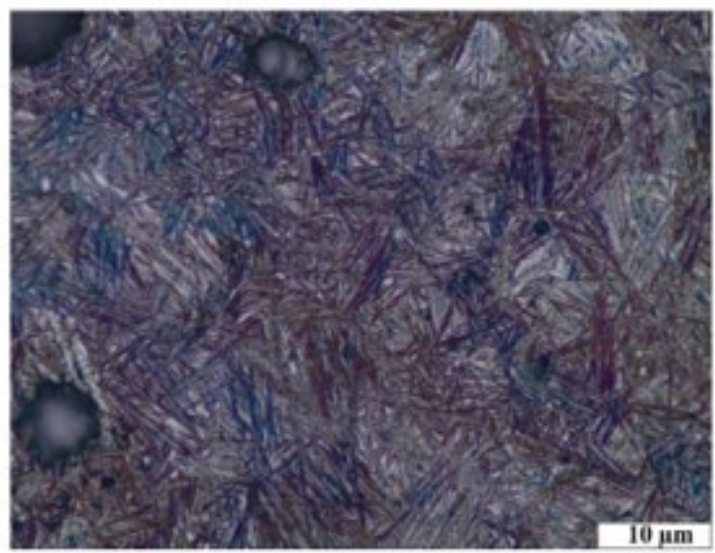

(b)

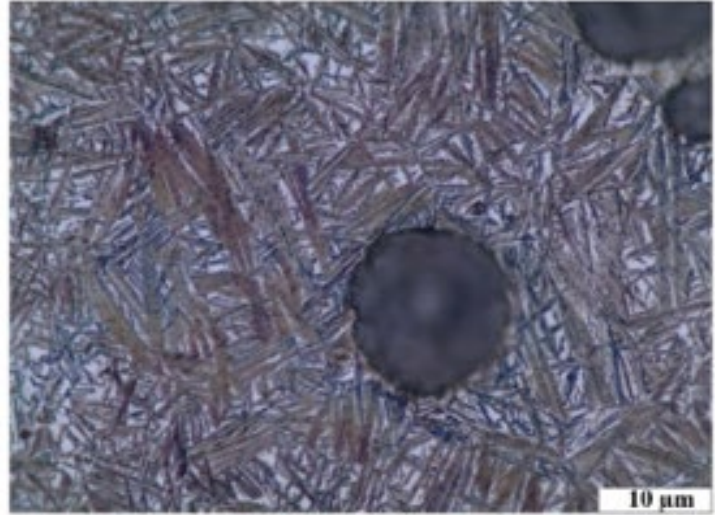

(d)

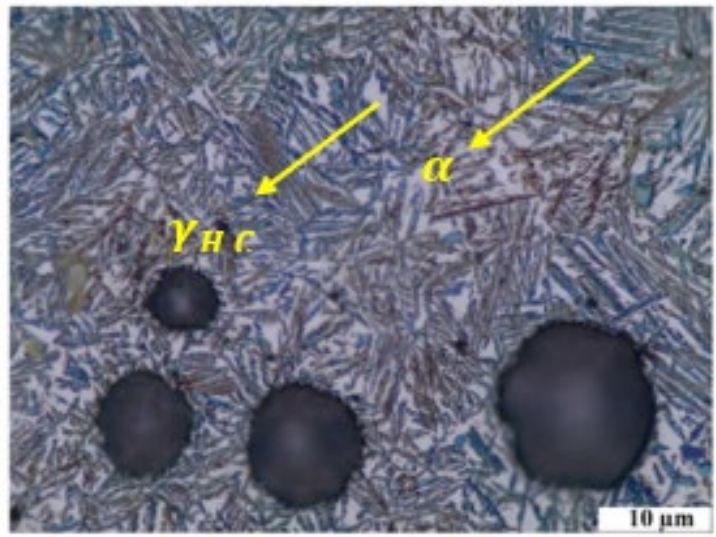

(f)

Figure 1: OM micrographs of ductile cast iron in (a) as-cast condition and austempered at (b) $300{ }^{\circ} \mathrm{C},(\mathrm{c}) 320^{\circ} \mathrm{C}$, (d) $340{ }^{\circ} \mathrm{C}$, (e) $360^{\circ} \mathrm{C}$ and (f) $380^{\circ} \mathrm{C}$. The dark needle-like structures are called acicular ferrite $(\alpha)$ and white regions are called carbon-enriched austenite $\left(\gamma_{H C}\right)$. 


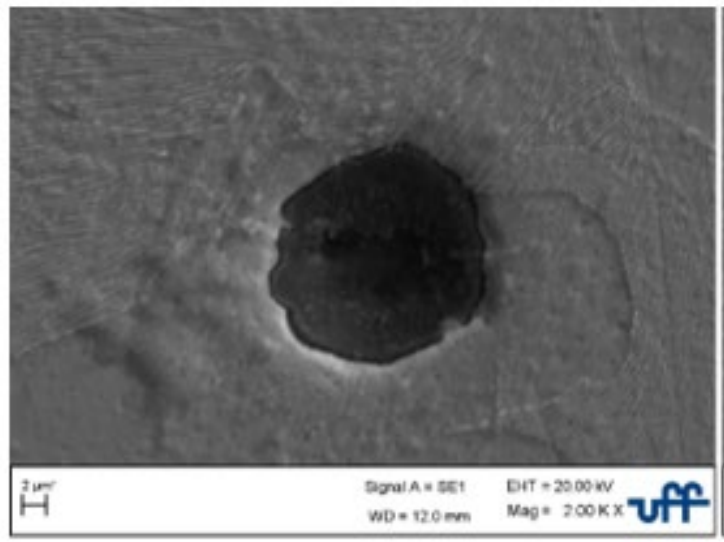

(a)

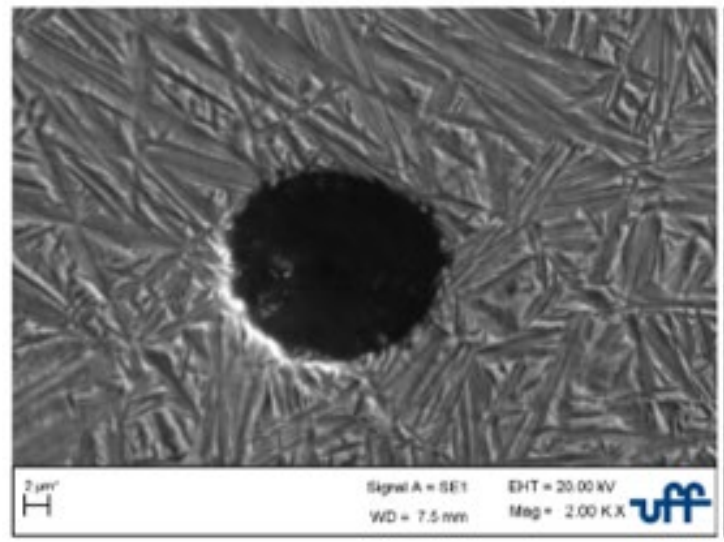

(c)

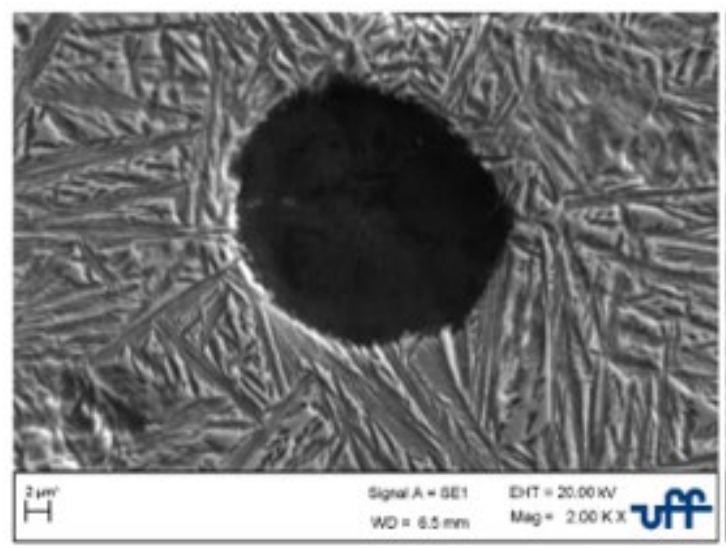

(e)

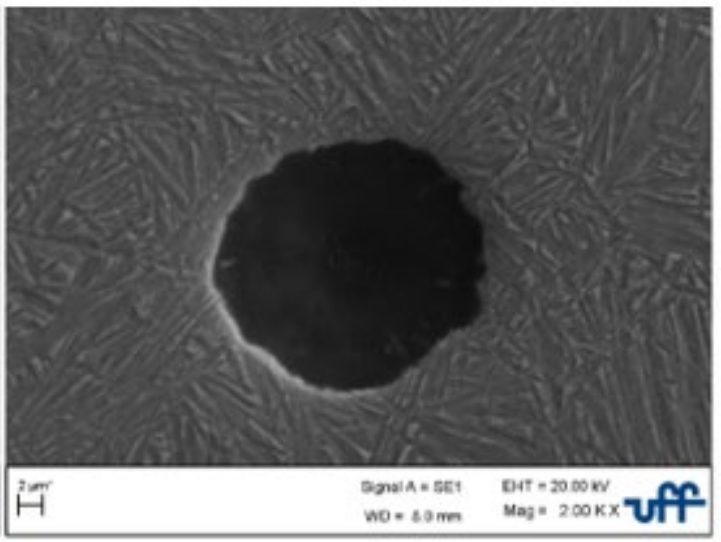

(b)

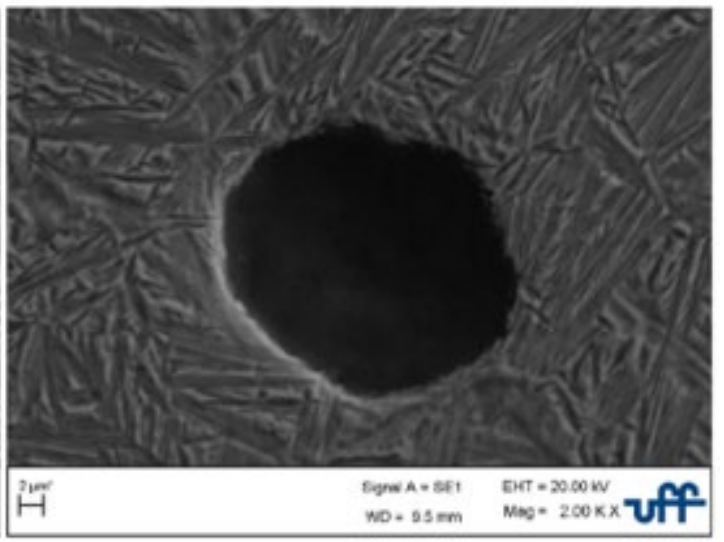

(d)

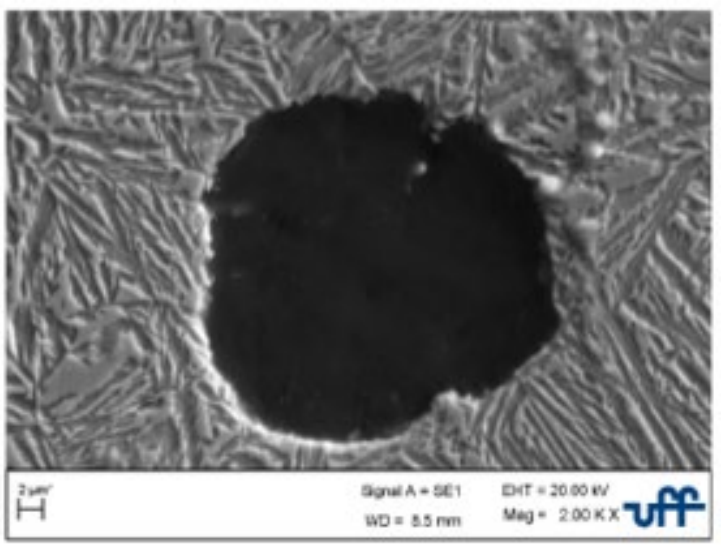

(f)

Figure 2: SEM micrographs of ductile cast iron in (a) as-cast condition and austempered at (b) $300^{\circ} \mathrm{C},(\mathrm{c}) 320^{\circ} \mathrm{C}$, (d) $340{ }^{\circ} \mathrm{C}$, (e) $360{ }^{\circ} \mathrm{C}$ and (f) $380{ }^{\circ} \mathrm{C}$

The classification of graphite nodules is shown in Table 2, which specifies the form, size, nodule count, nodularity, and nodules present. All samples have the graphite form type I, whose graphite is nodular in shape and is the normal and usually desirable graphite form in ductile iron, and the size of the graphite is 6 . According to the ASTM A247 - 17 standard, ductile irons typically exhibit a nodularity between 80 to $100 \%$, and the nodularity of all samples was above $90 \%$, so the values found are within the range specified by the standard. 
Influence of Austempering Time and Austempering Temperature in Microstructure and Mechanical Properties in Austempered Ductile Iron

Table 2: Classification of graphite nodules

\begin{tabular}{|c|c|c|c|c|c|}
\hline $\begin{array}{l}\text { Austempering time } \\
\text { and temperature }\end{array}$ & Form & Size & $\begin{array}{c}\text { Nodule count } \\
\text { (nodules } / \mathrm{mm}^{2} \text { ) }\end{array}$ & $\begin{array}{c}\text { Nodularity } \\
(\%)\end{array}$ & $\begin{array}{c}\text { Nodules } \\
\text { present (\%) }\end{array}$ \\
\hline As-cast & I & 6 & $1105.95 \pm 30.05$ & $94.17 \pm 0.43$ & $11.17 \pm 0.43$ \\
\hline $300^{\circ} \mathrm{C}-75 \mathrm{~min}$ & $\mathrm{I}$ & 6 & $1033.76 \pm 12.93$ & $93.10 \pm 0.71$ & $12.07 \pm 0.40$ \\
\hline $300^{\circ} \mathrm{C}-110 \mathrm{~min}$ & $\mathrm{I}$ & 6 & $1067.58 \pm 44.10$ & $92.93 \pm 0.60$ & $12.97 \pm 0.46$ \\
\hline $300^{\circ} \mathrm{C}-145 \mathrm{~min}$ & I & 6 & $1069.34 \pm 56.07$ & $93.32 \pm 0.63$ & $13.44 \pm 0.22$ \\
\hline $300^{\circ} \mathrm{C}-180 \mathrm{~min}$ & I & 6 & $1034.90 \pm 28.32$ & $92.42 \pm 0.68$ & $12.78 \pm 0.58$ \\
\hline $320^{\circ} \mathrm{C}-75 \mathrm{~min}$ & I & 6 & $1108.64 \pm 74.78$ & $91.79 \pm 0.68$ & $12.55 \pm 0.28$ \\
\hline $320^{\circ} \mathrm{C}-110 \mathrm{~min}$ & I & 6 & $1026.01 \pm 21.12$ & $92.66 \pm 0.53$ & $14.15 \pm 1.26$ \\
\hline $320^{\circ} \mathrm{C}-145 \min$ & I & 6 & $1066.34 \pm 34.31$ & $92.34 \pm 0.58$ & $13.99 \pm 0.31$ \\
\hline $320^{\circ} \mathrm{C}-180 \mathrm{~min}$ & I & 6 & $1118.88 \pm 36.25$ & $92.85 \pm 0.49$ & $13.95 \pm 0.86$ \\
\hline $340^{\circ} \mathrm{C}-75 \mathrm{~min}$ & I & 6 & $1134.80 \pm 24.17$ & $91.45 \pm 0.74$ & $13.50 \pm 1.14$ \\
\hline $340^{\circ} \mathrm{C}-110 \mathrm{~min}$ & I & 6 & $1058.48 \pm 54.96$ & $90.97 \pm 0.92$ & $16.18 \pm 0.61$ \\
\hline $340^{\circ} \mathrm{C}-145 \min$ & I & 6 & $1410.52 \pm 97.50$ & $92.82 \pm 0.74$ & $13.12 \pm 0.78$ \\
\hline $340^{\circ} \mathrm{C}-180 \mathrm{~min}$ & I & 6 & $1039.25 \pm 20.52$ & $92.76 \pm 0.58$ & $12.22 \pm 0.99$ \\
\hline $360^{\circ} \mathrm{C}-75 \mathrm{~min}$ & I & 6 & $1061.99 \pm 22.79$ & $91.19 \pm 0.81$ & $11.63 \pm 0.59$ \\
\hline $360^{\circ} \mathrm{C}-110 \min$ & I & 6 & $1714.67 \pm 84.10$ & $93.45 \pm 0.48$ & $11.80 \pm 0.19$ \\
\hline $360^{\circ} \mathrm{C}-145 \mathrm{~min}$ & I & 6 & $1091.89 \pm 24.15$ & $93.51 \pm 0.35$ & $12.72 \pm 0.18$ \\
\hline $360^{\circ} \mathrm{C}-180 \min$ & I & 6 & $1260.66 \pm 26.69$ & $92.92 \pm 0.67$ & $11.56 \pm 0.25$ \\
\hline $380^{\circ} \mathrm{C}-75 \mathrm{~min}$ & I & 6 & $1182.48 \pm 31.39$ & $93.60 \pm 0.59$ & $11.01 \pm 0.32$ \\
\hline $380^{\circ} \mathrm{C}-110 \mathrm{~min}$ & $\mathrm{I}$ & 6 & $1108.02 \pm 96.54$ & $93.71 \pm 0.43$ & $10.23 \pm 0.48$ \\
\hline $380^{\circ} \mathrm{C}-145 \min$ & I & 6 & $995.60 \pm 22.75$ & $92.88 \pm 0.61$ & $11.80 \pm 0.22$ \\
\hline $380^{\circ} \mathrm{C}-180 \mathrm{~min}$ & $\mathrm{I}$ & 6 & $1022.91 \pm 27.58$ & $94.02 \pm 0.48$ & $11.33 \pm 0.22$ \\
\hline
\end{tabular}

The appearance of the fracture could be obtained after the impact test. Fig. 3 presents the fractography of the samples after impact test (a) as-cast sample and austempered samples with the austempering time of 75 minutes, with austempering temperature, (b) $300{ }^{\circ} \mathrm{C}$, (c) $320^{\circ} \mathrm{C}$, (d) $340{ }^{\circ} \mathrm{C}$, (e) $360{ }^{\circ} \mathrm{C}$ and (f) $380{ }^{\circ} \mathrm{C}$. In Fig. 3a the as-cast sample showed a fragile transgranular fracture, due to the separation of crystalline planes and the aspect of the faceted fracture surface, because it absorbed little energy. In Fig.3b-f, the austempered samples showed a ductile fracture, due to the formation of microcavities, because they absorbed more energy than the as-cast sample.

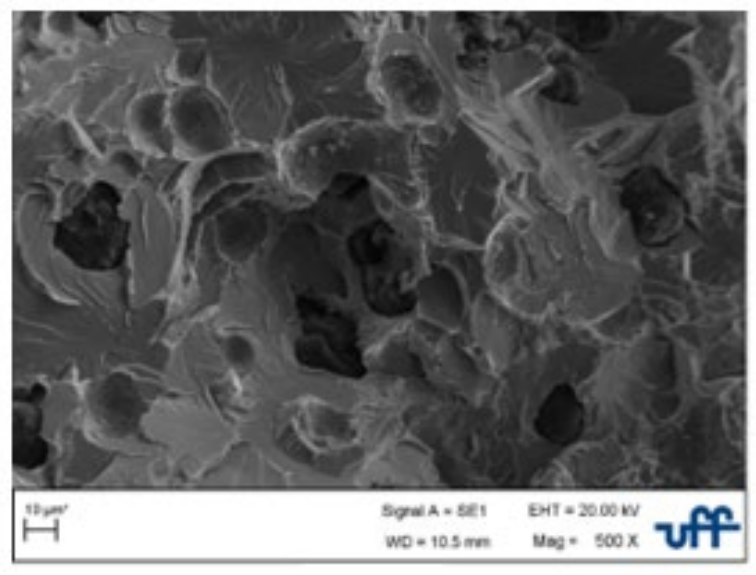

(a)

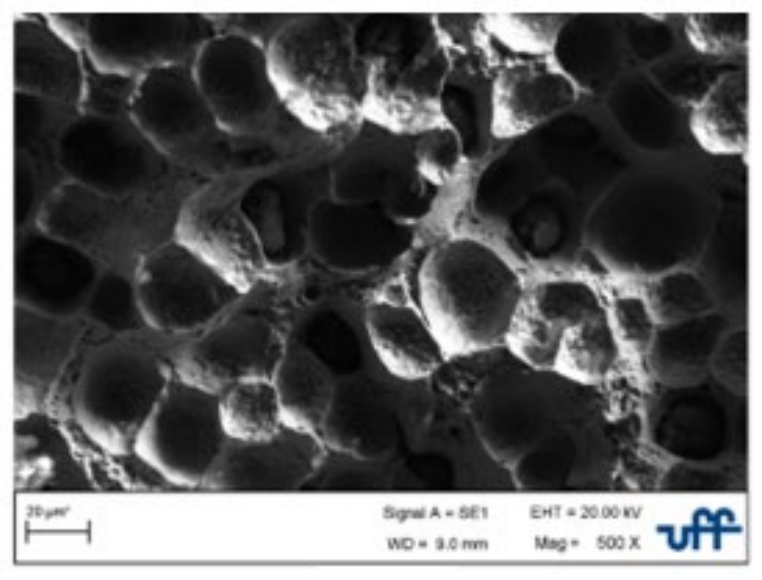

(b) 


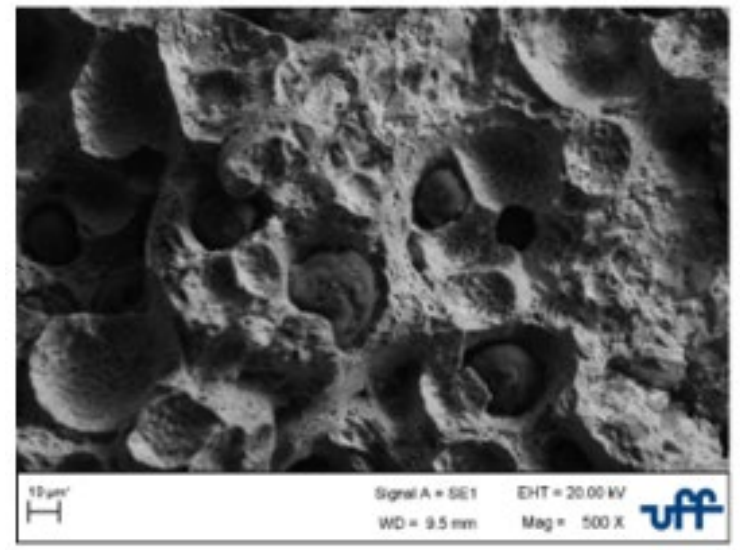

(c)

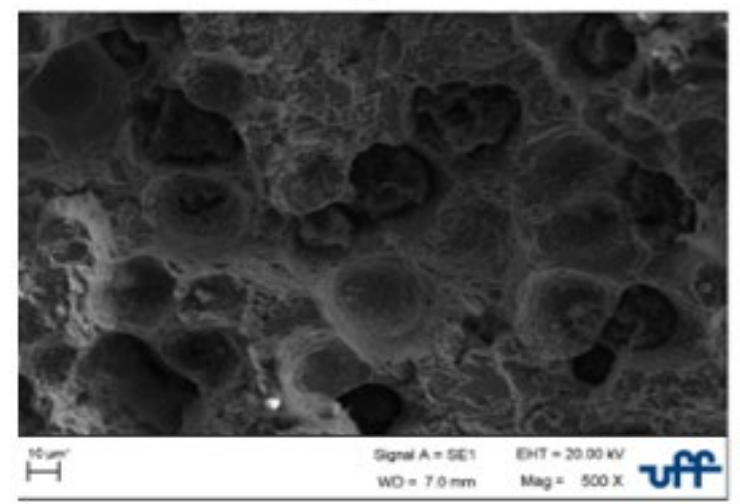

(e)

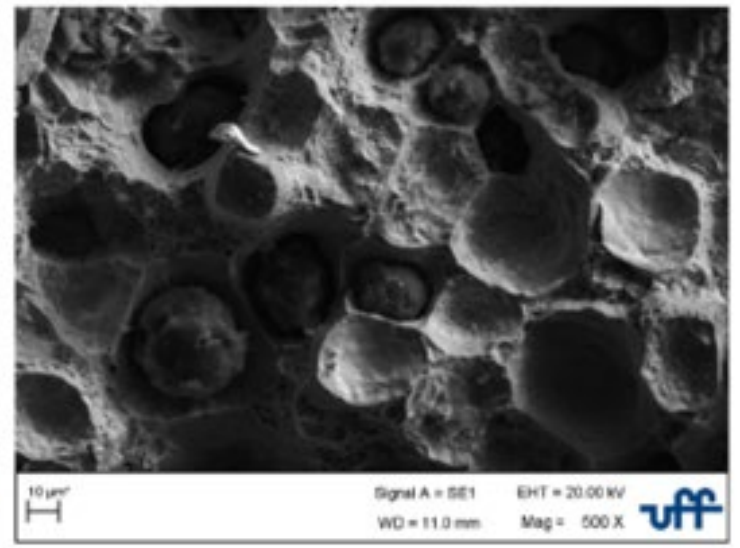

(d)

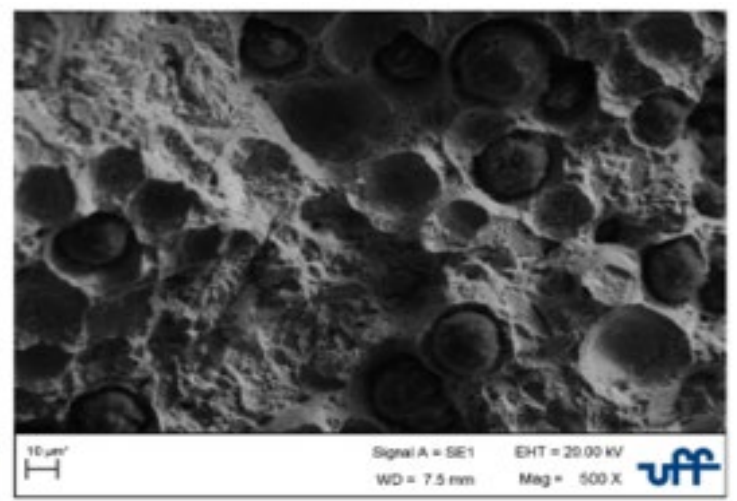

(f)

Figure 3: Fractured surface of the samples after the impact test (a) as-cast condition and austempered at (b) 300 ${ }^{\circ} \mathrm{C}$, (c) $320^{\circ} \mathrm{C}$, (d) $340{ }^{\circ} \mathrm{C}$, (e) $360^{\circ} \mathrm{C}$ and (f) $380{ }^{\circ} \mathrm{C}$

The austenite volume fraction, Brinell hardness and energy absorbed of all samples are shown in Table 3. The austenite content was found to increase as the austempering temperature and time increased. The sample austempered at $380{ }^{\circ} \mathrm{C}$ showed a considerably higher value of retained austenite than the sample austempered at $300{ }^{\circ} \mathrm{C}$. This difference is because its heat treatment promotes greater carbon enrichment in austenite due to higher austempering temperature and time.

The amount of retained austenite in ausferrite affects mechanical properties such as toughness and strength of ADIs. Table 3 shows that for austempered samples, brittleness increased as the volume fraction of austenite decreases with lower temperatures. Besides that, the Brinell hardnss increased significantly from the as-cast sample to the austempered samples and Brinell hardness presents a decrease with austempering temperature and time. Energy absorbed also increased significantly from the as-cast sample to the austempered samples and as the austempering temperature increases, the energy absorbed also increases.

Table 3: Brinell hardness, Energy absorbed and Austenite Content

\begin{tabular}{|c|c|c|c|}
\hline Austempering time and temperature & Brinell hardness (HB) & Energy Absorbed (J) & Austenite (\%) \\
\hline As-cast & $255 \pm 2.51$ & 35 & - \\
\hline $300^{\circ} \mathrm{C}-75 \mathrm{~min}$ & $458 \pm 2.83$ & 74 & $3.97 \pm 0.67$ \\
\hline $300^{\circ} \mathrm{C}-110 \mathrm{~min}$ & $456 \pm 3.76$ & 79 & $4.97 \pm 0.63$ \\
\hline $300^{\circ} \mathrm{C}-145 \mathrm{~min}$ & $450 \pm 2.11$ & 77 & $5.73 \pm 0.59$ \\
\hline $300^{\circ} \mathrm{C}-180 \mathrm{~min}$ & $447 \pm 6.16$ & 80 & $5.9 \pm 0.70$ \\
\hline $320^{\circ} \mathrm{C}-75 \mathrm{~min}$ & $414 \pm 9.97$ & 92 & $10.33 \pm 1.14$ \\
\hline $320^{\circ} \mathrm{C}-110 \mathrm{~min}$ & $413 \pm 3.60$ & 89 & $10.5 \pm 1.52$ \\
\hline $320^{\circ} \mathrm{C}-145 \mathrm{~min}$ & $404 \pm 6.52$ & 90 & $10.6 \pm 1.25$ \\
\hline
\end{tabular}


Influence of Austempering Time and Austempering Temperature in Microstructure and Mechanical Properties in Austempered Ductile Iron

\begin{tabular}{|c|c|c|c|}
\hline $320^{\circ} \mathrm{C}-180 \mathrm{~min}$ & $400 \pm 6.42$ & 96 & $11.6 \pm 0.96$ \\
\hline $340^{\circ} \mathrm{C}-75 \mathrm{~min}$ & $389 \pm 4.11$ & 104 & $13.5 \pm 0.89$ \\
\hline $340^{\circ} \mathrm{C}-110 \mathrm{~min}$ & $384 \pm 2.32$ & 99 & $14.43 \pm 1.09$ \\
\hline $340^{\circ} \mathrm{C}-145 \mathrm{~min}$ & $384 \pm 0.74$ & 106 & $14.8 \pm 0.99$ \\
\hline $340^{\circ} \mathrm{C}-180 \mathrm{~min}$ & $382 \pm 0.97$ & 108 & $14.93 \pm 0.96$ \\
\hline $360^{\circ} \mathrm{C}-75 \mathrm{~min}$ & $364 \pm 13.17$ & 118 & $16.87 \pm 1.21$ \\
\hline $360^{\circ} \mathrm{C}-110 \mathrm{~min}$ & $361 \pm 3.38$ & 113 & $17.57 \pm 1.59$ \\
\hline $360^{\circ} \mathrm{C}-145 \mathrm{~min}$ & $359 \pm 2.06$ & 115 & $17.97 \pm 1.19$ \\
\hline $360^{\circ} \mathrm{C}-180 \mathrm{~min}$ & $359 \pm 5.51$ & 119 & $18.07 \pm 0.95$ \\
\hline $380^{\circ} \mathrm{C}-75 \mathrm{~min}$ & $335 \pm 1.82$ & 127 & $23.33 \pm 1.49$ \\
\hline $380^{\circ} \mathrm{C}-110 \mathrm{~min}$ & $334 \pm 3.51$ & 124 & $23.7 \pm 2.17$ \\
\hline $380^{\circ} \mathrm{C}-145 \mathrm{~min}$ & $333 \pm 1.82$ & 120 & $24.93 \pm 1.66$ \\
\hline $380^{\circ} \mathrm{C}-180 \mathrm{~min}$ & $329 \pm 5.07$ & 130 & $25.73 \pm 2.24$ \\
\hline
\end{tabular}

The relationship between retained austenite and time in minutes, for austempering temperatures, is shown in Figure 4. It was possible to analyze that as the austempering temperature and time increase, the austenite retained also increases. Besides that, it was observed that temperature is a factor with a greater influence on the percentage of austenite retained than time.

\section{Retained Austenite x Time}

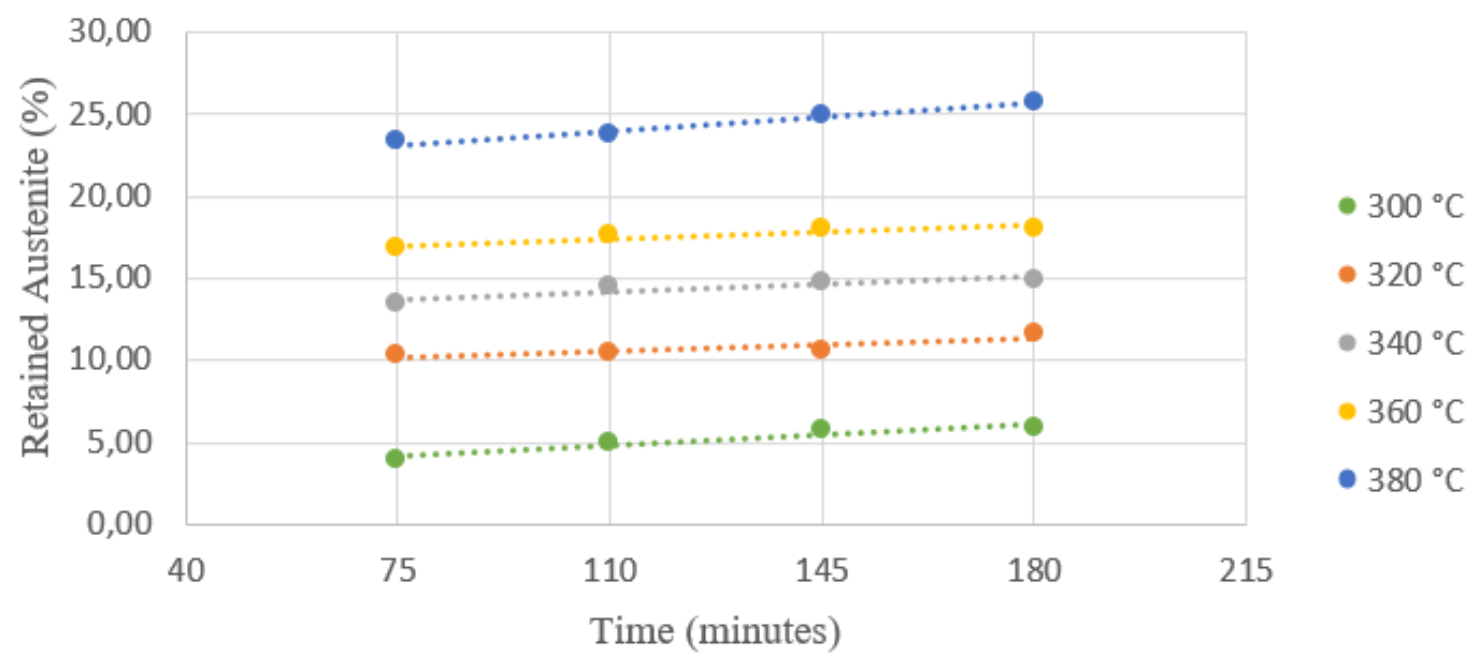

Figure 4: Relationship between retained austenite and time, for each austempering temperature

The relationship between Brinell hardness and time, in minutes, for austempering temperatures is shown in Figure 5. It was possible to observe that as the austempering temperature and time increase, the hardness is reduced, due to the increase of the retained austenite. Therefore, the hardness of the material showed a result inversely proportional to the time and austempering temperature, Figure 5.

As time is a less influential parameter when compared to austempering temperature, showed in Figure 4 and 5. a graph was created, represented in Fig. 6, with the average values of energy absorbed by impact, in Joule, for each temperature, 300, 320, 340, 360 and $380{ }^{\circ} \mathrm{C}$. When analyzing Figure 6, it is concluded that as the austempering temperature increases, the energy absorbed by impact also increases. 


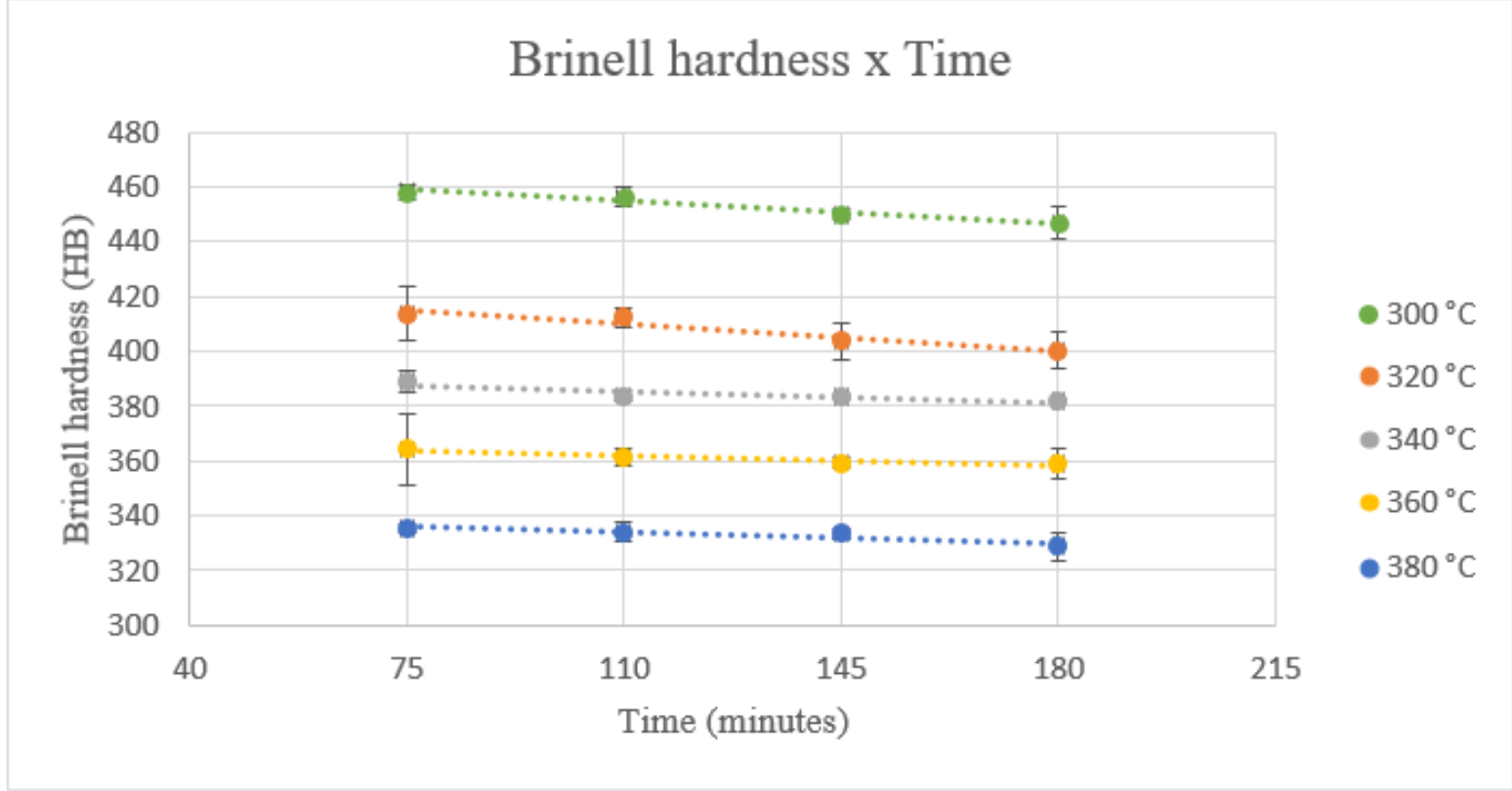

Figure 5: Relationship between Brinell hardness and time, for each austempering temperature

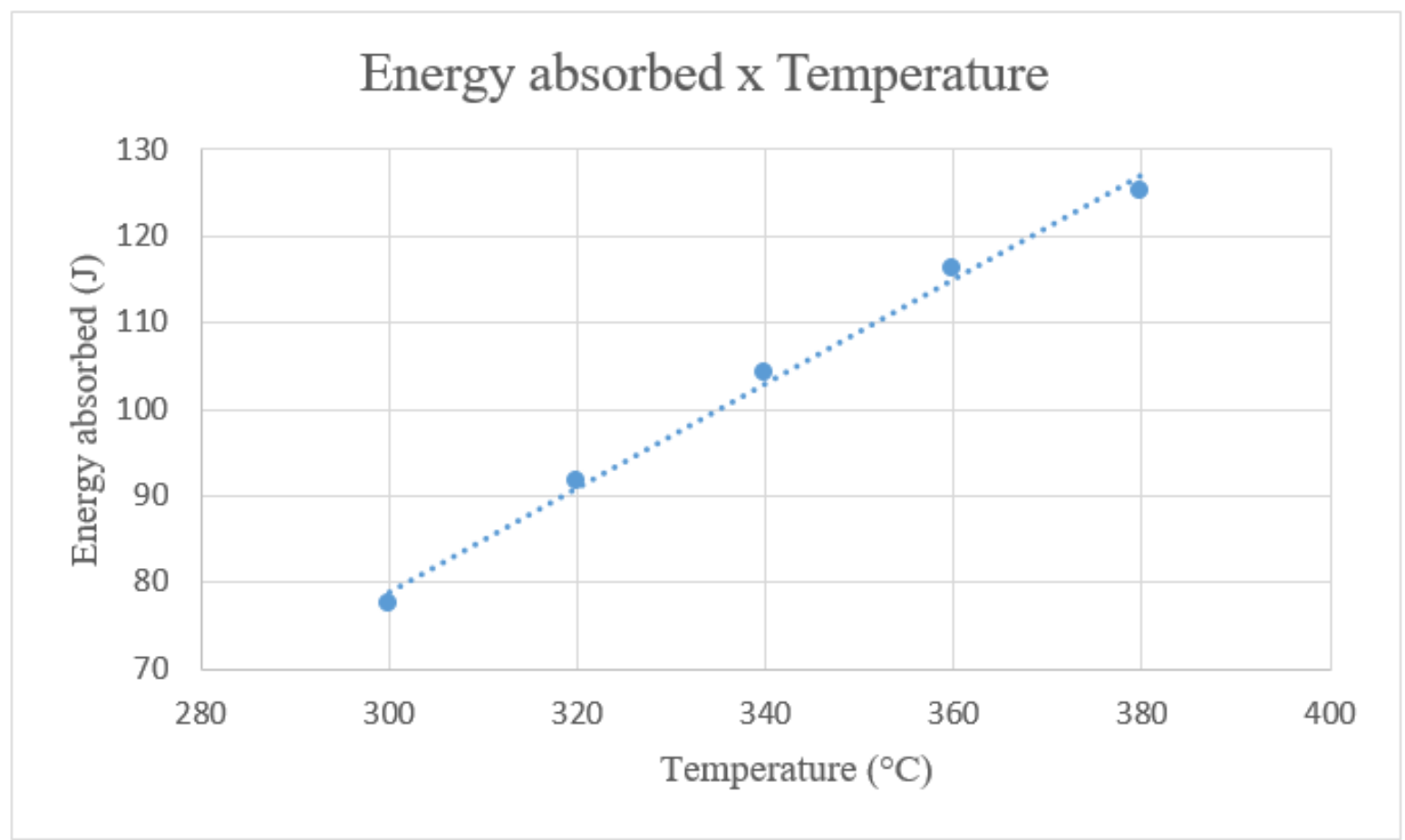

Figure 6: Relationship between energy absorbed and austempering temperature

Figure 7 shows the relationship between the percentage of retained austenite and Brinell hardness. The austempering temperature increases, the material's hardness decreases. Thus, it is possible to observe in Figure 7 that as the hardness decreases, the percentage of retained austenite increases. To obtain the relationship between retained austenite and Brinell hardness, it was determined that the correlation coefficient between them is -0.99 , which indicates a strong relationship between them because as the correlation coefficient approaches 1 or -1 , the relationship is stronger. The percentage of austenite retained and Brinell hardness is inversely proportional. 
Influence of Austempering Time and Austempering Temperature in Microstructure and Mechanical Properties in Austempered Ductile Iron

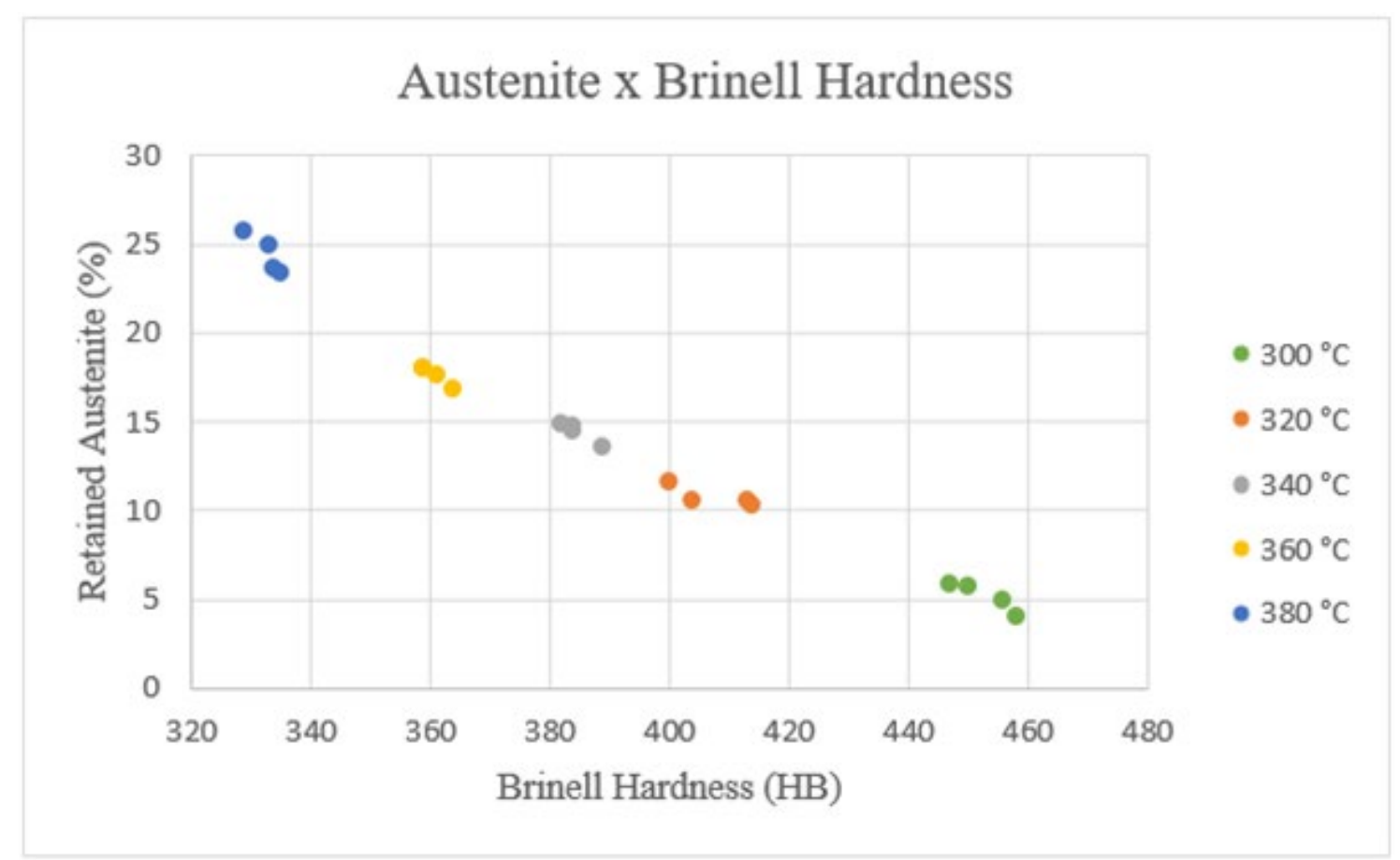

Figure 7: Relationship between retained austenite and Brinell hardness

Figure 8 shows the relationship between the percentage of austenite retained and energy absorbed. The percentage of austenite retained, and the energy absorbed is proportional. To obtain the relationship between the retained austenite and the impact energy, it was determined that the correlation coefficient between them is 0.97 , which indicates a good relationship between both. As the energy absorbed increases the retained austenite also increases, therefore, the material becomes more ductile, and this was verified by the microscopic study of fractured surfaces, Figure 3.

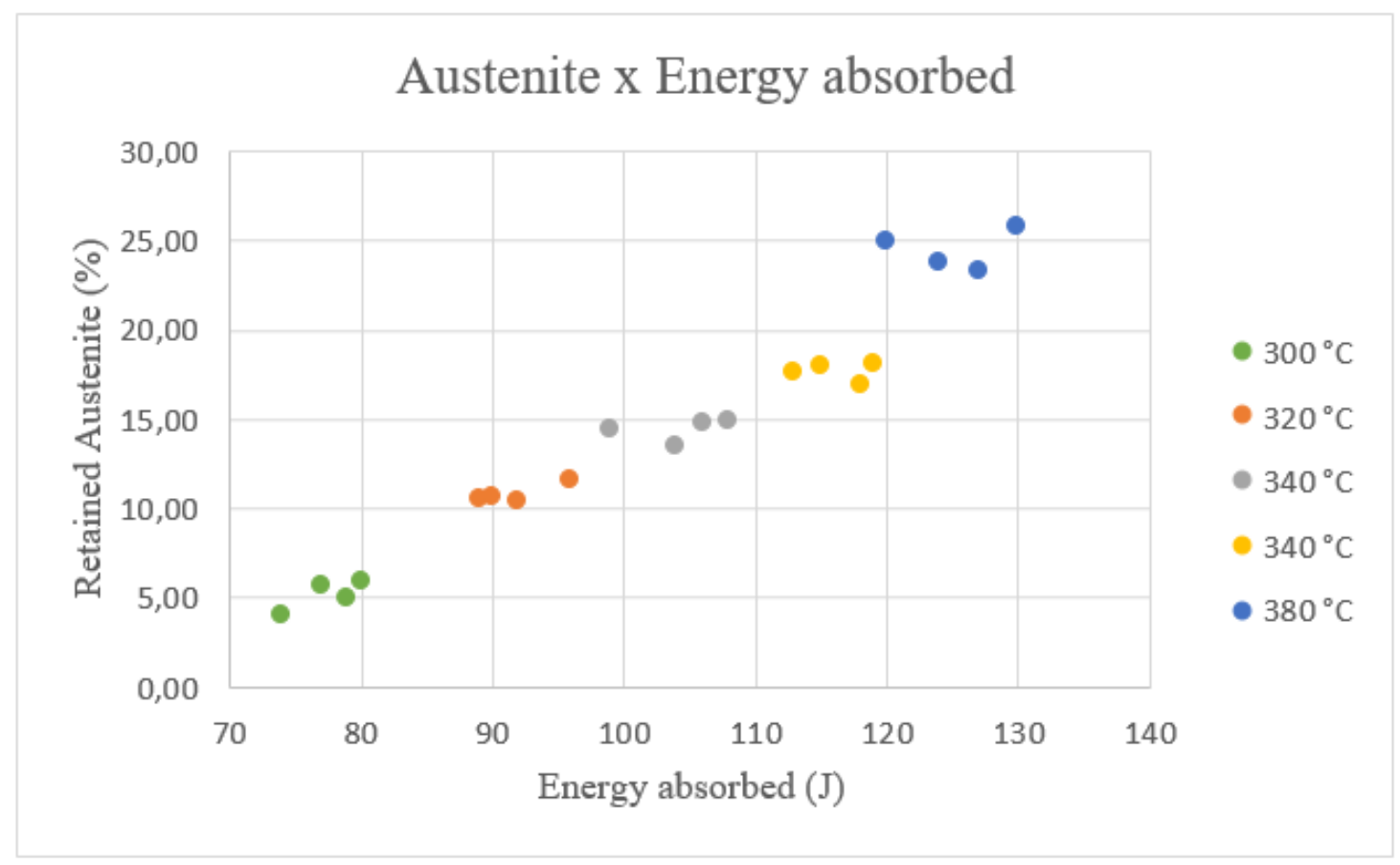

Figure 8: Relationship between retained austenite and energy absorbed 


\section{CONCLUSIONS AND RECOMMENDATIONS}

Based on the results of this study, the following conclusions may be drawn:

1) The as-cast sample has a graphite nodule, ferrite, and perlite. Both the as-cast sample and the austempered samples have the same shape (I), size 6, and nodularity greater than $90 \%$.

2) All the austempered samples presented a graphite nodule, acicular ferrite, and austenite with high carbon content in their microstructure.

3) The Brinell hardness and energy absorbed obtained after austempering treatment on nodular cast iron are greater than the same properties without heat treatment.

4) There is a strong relationship between austempering temperatures and Brinell hardness and energy absorbed. The samples treated at higher austempering temperatures showed less hardness and high energy absorbed. This is related to the amount of retained austenite. High austempering temperatures lead to higher volumes of residual austenite, with an increase in toughness. As the temperature increases, the retained austenite also increases, because of the greater diffusion of carbon.

5) The influence of austempering temperature on the microstructure, hardness, and energy absorbed in ADI is much more significant than the influence of time. Besides that, at higher austempering temperatures, there is a coarser microstructure than at lower temperatures.

6) The highest retained austenite and energy absorbed were $25.73 \%$ and $130 \mathrm{~J}$, respectively, for the austempered sample at $380^{\circ} \mathrm{C}$ and 180 minutes. On the other hand, the highest value of Brinell hardness was $458 \mathrm{HB}$, for the austempered sample at $300^{\circ} \mathrm{C}$ and 75 minutes. This range of mechanical properties obtained can be a factor in choosing which austempering temperature to choose for the type of application of the austempered ductile iron.

\section{SOURCES OF FUNDING}

None.

\section{CONFLICT OF INTEREST}

None.

\section{ACKNOWLEDGMENT}

The author would like to thank PGMEC/EEIMVR/UFF and to Tupy's foundry for the alloy samples.

\section{REFERENCES}

[1] Alves, V. C. C. et al. Correlation between Microstructure and Mechanical Properties of Austempered Ductile Irons. Materials Science Forum. 925, 2018, 203 - 209.

[2] Donnini, R. et al. Assessment of the Microstructure Evolution of an Austempered Ductile Iron During Austempering Process Through Strain Hardening Analysis. Metals and Materials International. Vol 3, No 5, 2017, $855-864$.

[3] Panneerselvam, S. et al. An Investigation on the Stability of Austenite in Austempered Ductile Cast Iron (ADI), Materials Science \& Engineering A. 626, 2014, 237 - 246.

[4] Wadageri, C. S., Kurahatti, R.V. Review of Enhancement in Mechanical Properties using Austempered Ductile Iron (ADI). International Journal of Advanced Engineering Research and Science. Vol 3, 2016, 2349 - 6495.

[5] Zhang, J. et al. Microstructure and mechanical properties of austempered ductile iron with different strength grades. Materials Letters. 119, 2014, $47-50$.

[6] Kim, Y. J. et al. Investigation into mechanical properties of austempered ductile cast iron (ADI) in accordance with austempering temperature. Materials Letters 62, 2007, 357-360.

[7] Putatunda, S. K. et al. Development of Austenite Free ADI (Austempered Ductile Cast Iron). Materials Science and Engineering A 435-436, 2006, 112 - 122. 
Influence of Austempering Time and Austempering Temperature in Microstructure and Mechanical Properties in Austempered Ductile Iron

[8] American Society for Testing and Materials - ASTM. Standard Specification for Austempered Ductile Iron Castings. ASTM. A897M /A897M - 15. 2015.

[9] Voigt, R. C. Austempered Ductile Iron - Processing and Properties, Cast Metals. 2:2, 1989, 71-93.

[10] Putatunda, S. K. Comparison of the Mechanical Properties of Austempered Ductile Cast Iron (ADI) Processed by Conventional and Step-Down Austempering Process. Materials and Manufacturing Processes. 25, 2010, $749-757$.

[11] Harding, R. A. The production, properties and automotive applications of austempered ductile iron. Kovove Mater, 45, 2007, 1-16.

[12] Sellamuthu, P. et al. Austempered Ductile Iron (ADI): Influence of Austempering Temperature on Microstructure, Mechanical and Wear Properties and Energy Consumption. MDPI. Metals 2018, 8, 53.

[13] Panneerselvam, S. et al. Influence of intercritical austempering on the microstructure and mechanical properties of austempered ductile cast iron (ADI). Materials Science \& Engineering A. 694, 2017, 72 - 80.

[14] Eric, O. et al. Microstructure and toughness of CuNiMo austempered ductile iron. Materials Letters. 58, 2004, 2707 - 2711.

[15] American Society for Testing and Materials - ASTM. Standard Test Method for Evaluating the Microstructure of Graphite in Iron Castings. ASTM A247 - 17. 2017.

[16] American Society for Testing and Materials - ASTM. Standard Test Method for Determining Nodularity and Nodule Count in Ductile Iron Using Image Analysis. ASTM E2567 - 16a. 2016.

[17] American Society for Testing and Materials - ASTM. Standard Test Method for Brinell Hardness of Metallic Materials. ASTM E10 - 18. 2018.

[18] American Society for Testing and Materials - ASTM. Standard Test Methods for Notched Bar Impact Testing of Metallic Materials. ASTM E23-16b. 2016.

[19] Kovacs, B. V. Austempered ductile iron: fact and function. Modern Casting. Vol. 80, n. 3, 1990, 38-41.

[20] Murcia, S.C.; Ossa, E.A.; Celentano, D.J. Nodule Evolution of Ductile Cast Iron During Solidification. The Minerals, Metals \& Materials Society. 45B, 2014, 707 - 718. 